\title{
Creative inquiry: Exploring teacher researcher self- reflexivity through arts-based self-study
}

\section{Kirsten Woitek}

College of Education and Human Development, George Mason University, Fairfax, Virginia, USA

kwoitek@gmu.edu

https://orcid.org/0000-0001-8341-3756

(Received: 16 September 2019; accepted: 7 February 2020)

\section{Abstract}

This teacher researcher self-study examines self-reflexive learning using artwork and poetic devices in order to explore my identity as an English to speakers of other languages (ESOL) teacher. It demonstrates how I developed my creative process and how my artistic research practices deepened my findings. The data includes my reflective journal and analytic memos, my teacher journal, personal notes from students, and teacher/colleague free writes. I also used a mirror cinquain poem as an analytical tool to help clarify my selfassessment. Through the analysis of my process and products, I gained perspective about myself as a teacher, explored my lived teacher experiences, and discovered how the use of inventive methods allowed new knowledge to inform my understanding of my teacher self.

Keywords: artwork, ESOL teacher, identity, inventive methods, poetic devices, self-reflexive, teacher researcher

\section{Introduction}

\author{
"Not my flag!" \\ Many distractions. \\ Flags. Salvadoran flag on backpacks and t-shirts. \\ Lost and confused, they insisted that the Israeli flag belonged to him. \\ He was Palestinian and wanted to learn Spanish more than English- \\ to fit in.
}

In this study, I explore how self-reflexivity and arts-based methods informed my exploration of my identity as a teacher of English to speakers of other languages (ESOL). In the classroom setting, there is often a tension in the self in relation to others (Bullough \& Pinnegar, 2001). Therefore, how a teacher develops an identity, and recognises and relates to 
students' identities, are significant factors in the teaching of English learners (ELs) in the language classroom. Identity is a construct that is both complex and multifaceted and can fluctuate and shift (Block, 2007; Norton Peirce, 1995). Accordingly, through an active process of self-reflexivity using artwork and poetry, this study explores some of the complexities and challenges that shape teacher identity. It will be useful to other ESOL teachers who wish to explore their own teacher identities. The integration and enactment of various arts-based methods will also be beneficial to other researchers exploring identity.

This study aimed to explore the research question: "How can the use of artwork and poetic devices inform my understanding of my identity as an ESOL teacher?"

\section{Literature review}

The relationship between identity and language, and the effects of the social and political environment on the language learner, are important concepts in EL identity research (Block, 2013; Norton \& Toohey, 2011; Pavlenko, 2012). Language and identity research considers the relationships of the language learner within their surroundings, with particular attention given to the classroom setting. This research often applies issues of social inequality as well as issues of power in relation to language learner identity (Kubota, 2004; May, 2012; McKinney \& Norton, 2008). The research is specifically personal, and primarily associated with the student's social and cultural setting. Therefore, studies that look at teacher identity can further inform language learner identity as it relates to the educational environment, and can help raise awareness about how teachers' perceptions impact student learning.

Teacher identity, as it relates to immigrant students, has been studied using various methods. To illustrate, in a study conducted from the perspective of a teacher working with immigrant students, Igoa (1995) found that her students' fragile identities and culture shock caused them to feel shyness and loneliness. In order to overcome these challenges, Igoa (1995) reflected on her own position as an immigrant and used that experience to connect to her students. Accordingly, the immigrant students preferred Igoa's classroom to others in the school because of the feeling of belonging and security (1995). In a similar finding, Pavlenko (2006) stated that many studies have shown that the language learner's sense of belonging is a significant factor in how students learn. Therefore, the teacher's ability to understand and empathise with the students directly affects a student's sense of belonging in an academic setting, and it is through studies on teacher identity that this understanding can be explored.

More recently, research by Rong and Hilburn (2017) found that teachers working with immigrants in North Carolina, USA, held a positive perspective toward their immigrant students' academic abilities and expressed genuine empathy toward them. However, the teachers felt hampered by the curriculum and the school setting and, therefore, did not advocate for their students (Rong \& Hilburn, 2017). Rong and Hilburn's (2017) study demonstrated how teacher identity affects teacher agency that, in turn, contributes to immigrant students' academic and social experiences in the classroom. Furthermore, teacher identity has been explored from its position of power, reinforcing the relational dynamic 
through which language teachers and students come to know themselves in the classroom (Morgan, 2004).

Thus, the influence of the teacher's sense of self is paramount to helping ELs learn. Selfstudy research is a way to gain an understanding of one's self and enables teachers to apply a critical lens to their professional values (Samaras, 2011). Samaras (2011) stated that as teachers use self-reflexivity, they work to gain a better view of their own teaching as well as the effect their teaching has on students. Self-study affects our students' learning as teachers examine who they are as people and how these characteristics influence their teaching (Samaras, Hicks, \& Berger, 2004). The following self-reflexive study expands on language and identity research by exploring teacher identity and its relationship to EL identity.

\section{Personal background}

My mother's journey to the United States as a refugee after World War II, her love of languages, cultures, and people sparked my interest in identity and its relationship to language:

My mother, like so many immigrants, came to the United States for a better life because her home and family had been lost through war. Therefore, she brought with her a sense of loss, something that I have only in recent years come to fully comprehend. (Reflective journal, February 3, 2019)

I worked as an ESOL teacher for five years before deciding to leave the profession to pursue a doctorate in education. In my role as an ESOL teacher, I interacted with students who were experiencing what my mother had experienced 50 years earlier. They were unable to speak English, and many had arrived in the United States without their immediate family and were living with extended family members in crowded apartments. I was a new teacher in a new setting and hired to teach them English. As a new teacher, I felt like an outsider. I did not know my place and did not understand the rules, schedule, and routine of a middle school environment, all of which helped me relate to the ELs' feelings of difference, as well as raised my awareness of how their identities were forming in a space that was, itself, operating in a state of scarcity and fear as the school struggled to meet adequate yearly progress (AYP) - the measure by which schools, districts, and states are held accountable for student performance under Title I of the No Child Left Behind Act (2001) —after two failing years. This pressure created a feeling of unrest and stress among the teachers and administrators. And it was in this environment that the ELs were forming their new academic, social, and personal identities. I felt compelled to study this experience in order to gain a greater understanding of my teacher identity. An extract from my reflective journal shows my deep concern for my students and my feelings of institutional stress,

The teachers were caring (even though many yelled), and the administrators were fairly open-minded and understanding of the students. As individuals, the teachers and administrators were not bad, mean, or indifferent. However, collectively, they were running a system that disregarded the individual. It felt a like a prison. The 
environment valued conformity and compliance. Many teachers felt that "these kids" needed this—controlled, limited, and restrained. I could feel myself both resisting and adapting to the setting and I wondered how the students who had to navigate and negotiate both the new school and the new language were developing their second language identity, especially under these circumstances. (February 20, 2019)

I wrote the above reflections using memory work (Mitchell, 2005; Naicker, 2014; PithouseMorgan, Mitchell, \& Moletsane, 2009) as I looked back at my first year of teaching. For this study, I also retrieved my old teacher journal and handwritten notes from students from my first year of teaching.

\section{Method}

The use of artistic expression allows for the emotional and private to emerge in a way that supports self-reflexivity. Therefore, I chose an arts-based self-study method to investigate my teacher identity. An arts-based approach is designed to expand human understanding and allows for an expressive form to be created that helps the individual become an empathetic participant in the lives of others and in the setting that is being explored (Barone \& Eisner, 2011).

\section{Context}

My research was situated in both the past and the present. I had a teacher journal and student notes from my teaching experience in 2011. My memory work, noted in my reflective journal and analytic memos, was conducted over a semester in 2019 during my doctoral studies in multilingual and multicultural education.

\section{Participants}

\section{Self}

My role as researcher and practitioner is evident in the reflective journal and analytic memos written in the early months of 2019, and my teacher journal written during my first year of teaching provided data from my past.

\section{Other participants}

The participants for this study also included the insights and perspectives of two ESOL teachers and critical friends. The ESOL teachers were selected through an email inquiry to my former teacher colleagues. The two ESOL teachers were the first to respond to my request to participate in the study. Their participation allowed for multiple ways to represent student and teacher identities, and these diverse perceptions reinforced and challenged the self-study (Feldman, 2003). Critical friends offered insight and perceptive comments to the practice of self-study (Costa \& Kallik, 1993; Klein, Riordan, Schwartz, \& Sotirhos, 2008; Samaras \& Sell, 2013; Wade, Fauske, \& Thompson, 2008). Pithouse-Morgan and van Laren (2012) supported this approach as an effective way to explore the data by beginning with the self and 
then moving towards collaboration. The critical friends were fellow students in the doctoral programme who provided weekly feedback and data interpretations. This served as a validation process (Samaras, 2011).

\section{Data collection}

I used multiple data sources: a reflective journal, analytic memos, my teacher journal, personal notes from students, and two ESOL teacher free writes. As I wrote my reflective journal and analytic memos, and incorporated my student notes and teacher journal from my first year of teaching, the use of creative expression to further my understanding of these data seemed appropriate and ideal. Analytic memos are written in the form of reflexivity and as a method of inquiry that reveals something new for the researcher that was not known before it was written (Richardson, 2003). Critical friends read my analytic memos and reflective journal, creating a dialogue that further informed my study. The two ESOL teachers participated in the study by providing their responses to free writes related to the visual image representation.

The reflective journal was written over the course of a few months in early 2019 during the fourth semester of my doctoral studies, and as a part of an advanced research methods course on self-study. I reflected back to my prior teaching experience, and approached this memory work by jotting down a thought, or thoughts, that arose at various times of the day in different settings. In these reflections, memories of my mother's immigrant story emerged and I wrote about that as part of my personal history. In addition to the reflective journal, an analytic memo included my search for a visual image that described my students, resulting in the discovery of a painting by Frida Kahlo. For me, the painting provided an emotional and accurate depiction of my students. These data formed from my own reflective writing exercise, my recollection of my mother's immigrant story, and a search for a visual image that could represent my students as I saw them. The data emerged interactively and reflexively with one another.

After I completed my reflective journal and analytic memos, I retrieved my teacher journal, which I had written during my first year of teaching nearly a decade ago. The journal was a requirement for my teacher certification programme. The time difference between the reflective journal and the teacher journal allowed for the possibility of multiple viewpoints to emerge and for ideas to be cemented from the data.

In order to gather data that would relate to my students, I needed to include my students' voices. Therefore, I collected my student thank-you notes from a box I had stored in my basement. I transcribed each handwritten note into a document so that I had all the student notes in one place. I kept the original notes intact, but also extracted frequently used words from them in order to find dominant expressions.

I maintained confidentiality by presenting the data in a way that ensured individuals' anonymity. I also omitted the name and location of the school and any identifying information. The two teachers were given a written consent letter that included the following 
information: the participant's acknowledgement of their voluntary role in the study, the purpose of the study, the benefits of the study, and a statement of confidentiality. Each participant was informed that their identity would not be revealed.

\section{Data analysis}

Wang, Coemans, Siegesmund, and Hannes (2017) emphasised that the process of artistic inquiry is creatively inspired. Therefore, in my data analysis, I used a Frida Kahlo painting and generated data from my past teacher journal and student notes, using poetry. The dualvoice poem (Johri, 2011) provided an opportunity for deeper consideration between my students' voices and me as teacher. I applied an arts-based inquiry to elicit responses from the two ESOL teachers (Wang, Coemans, Siegesmund, \& Hannes, 2017). I was able to enrich the data by relating my interpretation of the visual image to their interpretations of the painting in connection with their students. According to Savin-Baden and Wimpenny (2014), arts-related research allows for reflection on various human experiences.

I found themes by reading and rereading the data and sharing with my critical friends. The trustworthiness of my interpretations came from my critical friends as well as the positioning of the reflective journal in relation to my teacher journal, which were written eight years apart. I examined the data over a period of weeks, and coded by posing questions and notes to myself in order to identify themes and patterns (Saldaña, 2009). By examining multiple sources of data, common themes emerged. Quality analysis comes from finding themes in the multiple data sources (Pinnegar \& Hamilton, 2009). I developed support of the themes, and I generated critical friends' feedback in order to expand the themes. This form of triangulation-my writings, the notes from my students, and the critical friends and ESOL teachers' responses-enhanced the trustworthiness of the study.

I worked systematically by not reading the student notes or my teacher journal until after I had written both my analytic memos and reflective journal. This enabled the data to reveal pertinent details that may have been missed if I had read my teacher journal before reflection. By separating the past and the present, I was able to return to the teacher journal and reconsider my sense of EL identity in the earlier stages of my teacher training. This circular path of transparency revealed that my reflective journal was fraught with layers of my own memories of being a new teacher in a low-performing school. The ESOL teachers' and critical friends' input added a level of reliability that led to authentic and new ways of knowing (Brandenburg, 2009). Therefore, this integrated process produced a holistic and objective analysis of the data.

I used the Frida Kahlo (1933) painting, My Dress Hangs There, as a visual image of my students' experience in my classroom and in America. I discovered this Kahlo painting when I was researching images that characterised my students. It depicts various industrial images as well as skyscrapers and a church. In the centre is a traditional Mexican-style dress that is hanging on a clothes line suspended between a golf trophy and a toilet, both of which are set upon Roman columns. The painting was new to me and yet it quickly became 
emblematic of my study. In order to gain a deeper understanding of my teacher identity, I accessed multiple viewpoints by providing two of my ESOL teacher colleagues with the image and asked them to describe it in relation to their students, just as I had done.

I also composed a dual-voice poem as a way to analyse the data. This method enabled me to present my teacher journal entries and my student notes side by side, demonstrating a dialogic interaction in an inventive way. The poetry included the phrases and words that I catalogued and, through the deconstruction of the data into a format that could be organised through a poetic form, a narrative representation of the data emerged. The use of this artsbased method enriched my research and offered a co-constructed analysis that enabled the data to act together and in relation to one another. This poetic representation offers an understanding of the material that recognises the dialogue as a jointly constructed process between participant and researcher. The use of poetry served as a way to investigate, and more deeply examine, the data (Hopper \& Sanford, 2008). It helped extend my understanding of teacher and student subjectivities.

In essence, I was exploring and integrating various arts-based methods in new ways to more deeply explore my teacher identity. This methodological inventiveness (Pithouse-Morgan \& Samaras, 2020) allowed for my study to unfold and shift in a way that I had not predicted. The input from my peers (critical friends and the two teachers) and their interpretations enabled me to approach my teacher identity more critically. The teacher journal and reflective journal, combined with my analytic memos, my visual image, and student notes, formed a crystallisation of self-study methods as described by Samaras (2011). This crystallisation is a way for multiple angles of each method to help bring a greater understanding to the research (Samaras, 2011).

In my teacher journal that I had written during my first year as a teacher, I had noted that my students "had a desire to be fluent," "did not want an accent," "appeared to love language learning," and "found it difficult to read, write, speak, and be understood." From these extracts, I developed a theme that suggested the students had a desire to assimilate. Their language identity was uncertain because they wanted to belong to the new language community but did not have the language to belong: "Desire for community drew them back to their native language group." There were some students I had described as "lonesome and isolated" but, for the majority of the teacher journal, I depicted students as "ambitious," "wanting to learn," and "high-energy."

In my reflective journal and analytic memos, written eight years after my first year of teaching, my impressions were different. I recalled that "English was hard [for them]," "Spanish was dominant in the classroom," and "they struggled to fit in" and "missed home and missed their grandmothers." The reflective journal and analytic memos formed themes that described students as ambivalent toward their ability to assimilate. The students were also described as "stressed and struggling," "missing their home," and "confused," with only a few mentions of gratitude: "Students felt grateful for the small classroom setting." From this, themes developed signifying that students' identity and experiences were inimical to their new environment. 
Conversely, the two ESOL teachers who responded to the Kahlo (1933) painting and the questions about their perceptions and opinions of their ESOL students were positive in their responses: "Students enjoy learning," "they have pride in knowing Spanish and Ixil," "students have fun playing games," and "laugh a lot." The use of a painting and dual-voice poetry helped deepen my understanding of my teacher identity. Using each arts-based method allowed me to interpret my data providing a dynamic and interconnected analysis of the data. I used a mirror cinquain (Kolodji, 2005) as an analytical tool to help unpack my selfassessment in a concise manner. The two ESOL teachers' interpretations of the Kahlo painting helped illuminate my subjectivity. The reflective journal, analytic memos, teacher journal, and student notes worked together to provide a story over a period of time. The purpose of using these methods for my self-reflexivity was to expand my ways of knowing using inventive methods that would allow for the emotional and personal expression of my teacher identity to emerge. The next three sections describe more specifically the use of inventiveness using a visual image representation, a dual-voice poem, and a mirror cinquain.

\section{Method 1: Visual image representation}

I discovered the Frida Kahlo (1933) painting when looking for a visual representation of my students. I used this painting as a reference for the two ESOL teacher free writes by asking each of them to describe how the painting relates to, or does not relate to, their ELs. In linking the painting to their students, neither ESOL teacher connected their students to a sense of hopelessness. One teacher stated,

It doesn't [relate to my students]. The artist is not impressed by America-she hangs her dress here but where is her body? The brightest thing in the picture is the toilet? My students are more hopeful than this.

The other ESOL teacher interpreted the painting as an optimistic image and aligned it with her students. She commented,

The idea of experiences in their home country are very much at the forefront of their minds, as it is in the painting. My students have positive ideas about living in a new place and the promise it holds are all over the painting, as it is in our students' minds.

In contrast, my interpretation from my analytic memo was as follows:

I hoped to find an image that would depict identity in conflict with society, just as my students were struggling in their new environment. The lifeless dress surrounded by American images struck me immediately, and connects well with what my students were enduring in their lives in this new country.

For me, this painting was a visual metaphor of my students' identity-its overpowering industrial images and absence of the body in the hanging, empty dress. 
The inconsistency between our interpretations of our students' identities illuminated my subjectivity in a way that I had not foreseen. That is, the input from the ESOL teachers required me to self-reflect more critically. As I studied my reflective journal, I found that it contained descriptions of suffering, loss, and lack in relation to my ELs. Moreover, I synthesised the student notes, my teacher journal, and the ESOL teachers' interpretations and was able to discern that these data did not consist of despair. My reflective journal and my interpretation of the painting in relation to my students depict a greater sense of despondency than any other data. This finding suggests that memories are uniquely recalled and that they exist in relation to present experiences, thus producing unpredictability. Accordingly, the use of the painting as an interpretive image in relation to ELs helped me gain an understanding of my teacher perspective - in reflection, and how it changed over a period of time. From this reframing of my viewpoint, I realised that my memory tilted the EL experience in a direction that did not correspond with the other data. Therefore, I determined that I needed to assess the remaining data - the student notes and my teacher journal — in relation to each other in order to evaluate the interrelationship in real time. I chose to use a poetic device for this portion of the study.

\section{Method 2: Dual-voice poem}

Composing the dual-voice poem — using my students' voices and my journal entriesprovided a dialogue of perspectives within the environment we shared. The poetic discourse offered a profound and meaningful way to explore the student voices with the teacher voice, and demonstrated the complexities of identity. Identity includes how we perceive ourselves in relation to others (Norton, 2000). Therefore, the dual-voice poetry is a lyrical representation of mutual recognition between teacher and students, or self and other.

I love this class.

It's my favorite class.

Thank you for all lesson you teach me.

You always help me.

When I ask, you knew.

I wanna say thank you for this year of learning.

I swear I'm going to try learning English.
Language was the primary form of identity.

Those who were talkative in my class fell silent in other classes.

The girl from Camaroon and the boy from Israel were immediately on the periphery.

The boy from Mexico and the boy from Honduras were teased.

My goal was to unify the group through language.

Here, from the teacher perspective (shown on the right-hand side), the external experience is illuminated as a factor in identity. In my role as teacher, I am actively making sense of the surroundings and recognising the challenges. Conversely, the student voices are focused on one external factor - their teacher. My goal was to be a teacher who provided a stable and supportive classroom environment, and this is realised and recognised in the students' voices. Moreover, my concerns about student disengagement are offset by their positivity. The dual- 
voice structure illustrates this relationship, and the connection between the voices reinforces the identities that are forming in relation to one another.

Therefore, the poem shows the challenges of the students' struggle to find their sense of belonging in the classroom from multiple perspectives. The co-constructed analysis enabled the data to act together, and also shows my teacher identity forming around my perceptions of my students' needs. The following excerpt connects my interpretation of my students' identity and the students' self-identity of lack and dependence:

You had patience with me.

I wanna say thank you for all the patience

that you had with me.

I know it's hard understanding a person that

doesn't speak the same language.

Thank you so much for the encouragement I receive for you.
He wanted friends. He wanted to fit in.

Asking to eat lunch in my classroom.

She slept most of the time.

As they learned English, they stopped wearing the flag.

Expressed annoyance with their parents who do not speak English.

Our one-room schoolhouse.

The students' use of "patience" and "encouragement" suggests that they feel a sense of deficiency in their inability to speak English, and they are apologetic about it. Their gratitude expresses appreciation as well as distress. Simultaneously, my entry corresponds and responds to these ambivalent expressions of self by conveying the exchange of language assimilation with native language abandonment- "annoyance with their parents who do not speak English." This interconnection between language and identity is observable through the use of the dialogue that occurs in dual-voice poetry. Moreover, this poem allows for the affective themes of identity to develop, showing optimism and inspiration, as well as the patterns that emerge from my voice which display challenges of assimilation and language ambivalence among my students. Therefore, this dual-voice poem incorporates a creative and critical rendering of how teacher identity forms in relation to the students' identity, and vice versa, in the EL classroom.

\section{Method 3: Mirror cinquain}

According to Kolodji (2005), mirror cinquains are two-stanza cinquain (5-line) sequences with syllabic counts of 2-4-6-8-2 and 2-8-6-4-2, respectively. In my self-study, I produced a series of mirror cinquains using the 10-line patterns to reflect my self-analysis with the five foci in the methodological components of self-study. These five foci are personal situated inquiry, critical collaborative inquiry, improved learning, transparent and systematic research process, and knowledge generation and presentation (Samaras, 2011). According to Samaras (2011), these are guidelines for conducting self-study research. Therefore, the title of each set of mirror cinquains is one of the five foci, and its stanzas mirror my self-assessment as it 
relates to that focus. The restrictions of the poetic form's syllable pattern enforced brevity as well as emphasised contemplation and reflection.

Mirror cinquains

Personal Situated Inquiry

My lens,

My inquiry.

Self-assess my practice.

Role of culture on my theories,

Impact.

Journals,

From today's reflections and thoughts

To those scribed years ago.

Inconsistent.

Re-think.

Critical Collaborative Inquiry

Expand

Self-study work,

Collaborate to gain

Divergent perspectives and views;

CF. ${ }^{1}$

$\mathrm{CF}$

Supportive of my self-study.

Questioning my ideas,

Which gave me pause.

Shared thoughts.

Improved Learning

Impact

Education

For students and teachers.

Self-study research can help schools

Improve.

So what?

Teacher identity matters.

Critical friends 
Messy but enlightening.

Changed perspectives

Over time.

\section{Transparent and Systematic Research Process}

Data

Clear, accurate.

CF probing questions;

Open to different perspectives.

Critique.

Stories

Shared, analysis and coding.

Confront my assumptions.

Unexpected.

New thoughts.

\section{Knowledge Generation and Presentation}

Knowledge

Generated.

Important for others.

Contributes to research and thought.

Useful.

Teacher

Ambivalent to changing self.

Helps me understand them

By knowing self.

Perceive.

\section{Discussion}

The methodological components of self-study are also guidelines for teachers to conduct selfstudy research (Samaras, 2011). In my self-study assessment, I produced a set of mirror cinquains using Samaras' (2011) five foci to directly reflect (mirror) my role in the methodological inventiveness of this self-reflexive study.

Personal situated inquiry

Arts-based research reveals that which may not be obvious, leading toward new understandings (Savin-Baden \& Wimpenny, 2014). Therefore, the inventiveness of multiple 
methods — visual image, reflection, poetry—was used as ways to understand my own subjectivity in both time and place.

\section{Critical collaborative inquiry}

Situating the arts-based methods in a dialogic process-visual metaphor with ESOL teacher interpretations, reflections with original journal entries, and poetry with student notesprovided insight about my own teacher identity by considering it in relation to others.

\section{Improved learning}

This study shows how self-reflexive educational research can benefit from methodological inventiveness. For example, the Frida Kahlo (1933) painting generated contradictory interpretations between the ESOL teachers' perceptions of their students and my observations of my students. This discord compelled me to reflect further into my insights through the use of a dual-voice poem and mirror cinquains, providing improved learning about myself and my interpretation of my students.

\section{Transparent and systematic research process}

I worked methodically throughout this study. I wrote my reflective journal and analytic memos, which included the interpretation of the visual image by Frida Kahlo, at the beginning of the process. Subsequently, I focused on the student notes and my teacher journal and engaged with those in the form of poetry. Arts-informed inquiry focuses on the use of arts as a way to represent and examine the experience of the researcher and participants (Savin-Baden \& Wimpenny, 2014). This is depicted in the dual-voice poem that showed ambivalence in the students - as they expressed joy and sadness, excitement and longingbut not a sense of oppression as I had described their experience in my reflective journal and analytic memos.

\section{Knowledge generation and presentation}

Arts-based approaches to research enable new knowledge to be generated through meaningful forms of artistic expression (Weber, 2014). Therefore, through the use of artsbased methods in self-reflexivity, this study revealed new insight into my teacher identity through the emergence of data that showed how I allowed my own sense of dislike and discomfort with the institutional inflexibility to be projected onto my students. Over a period away from the actual environment, my students - in the passing of time-became more helpless in my mind. This knowledge is enlightening for me as a researcher and practitioner because it revealed my subjectivities in the research and how these positions can conflict with one another.

\section{Conclusion}

In self-study research, the researcher allows herself to be vulnerable (Samaras, 2011). My point of vulnerability arose after I collected and analysed the data from my critical friends 
and the ESOL teachers, as well as reread my teacher journal. During the process of analysis, I came to know more about myself, which caused me some discomfort because it showed a teacher identity shift in myself that I did not know had happened. This study also brought forth the realisation of how positive my students were in their thank-you notes (something that one of my critical friends had remarked on as well). Also, as I reviewed my teacher journal entries, I realised how optimistic I had once been about the students and their learning. However, in returning to my reflections, there are indications that I had got stuck on the hurdles of the institutional stress and rigidity. My memory work recorded in my reflective journal refers to the students' school environment as "like a prison" and their home environments as "living with strangers in bad conditions," suggesting a focus on sympathy that could be categorised as pity. This is an important admission and something that teachers (and educational researchers) need to be aware of. As this knowledge revealed itself in the data, it was uncomfortable - and I asked myself: Wasn't I just a caring teacher who knew the suffering of the immigrant story through the stories my mother shared with me? Didn't this position of knowing struggle enable me to be more compassionate and empathetic to those who had lost so much? Why wasn't I so sure anymore?

The methodological inventiveness of this self-reflexive study exposed my gaps and lapses of memory. In my teacher journal-written in real-time while working directly with the students - the theme around student identity developed as ambivalent, showing both positive and negative attitudes toward assimilation. But years later, my reflective journal and analytic memos consist of a dismal view of their language identity development: "The institution was more important than the individual" and "[students] only wanted to speak Spanish." However, neither my teacher journal nor the student notes supported this unfavourable view of language and assimilation.

It was through the participation of the ESOL teachers that I first realised that my concern for my students had, in the time lapse between teaching and reflecting, shifted to a sense of despair. The ESOL teachers' comments depicted their students as hopeful whereas I summarised my students experience (in relation to the Kahlo (1933) painting) as follows: "The lifeless dress surrounded by American images struck me immediately, and connects well with my students' experience." When I referred to my teacher journal entries, I noticed that my sense of my students had been more optimistic when I was teaching: "As they learned English, they stopped wearing the flag" and "they spoke English and laughed." Using an arts-based method revealed more questions and generated more uncertainties to my selfreflexive study. According to Barone and Eisner (2011), this is part of the value of undertaking a study using arts-based methods.

Importantly, this self-study demonstrates how this swing toward a negative view of my students' experience arose in the absence of being with the students. When I embarked on this study, I had left the teaching profession and been a graduate student for over two years. In considering the changes that shifted my impressions of the students to a vulnerable state, I had to consider how I had changed. The greatest shift was going from being a practitioner to 
being a researcher. This reinforces the notion that teacher researchers need to stay active in their practice.

By combining various arts-based methods into my self-reflexive study, I gained insight into my teaching identity. Creating the poem encouraged me to explore relations between the self and practice, personalised my meaning making, and offered an opportunity for critical analysis (Samaras, 2010). The multiple creative approaches demonstrated how inventive methods, such as poetry and art, can provide the opportunity to explore ourselves and our teacher identities more deeply. The self-knowledge generated by these artistic methods can help teachers grow professionally. This, in turn, benefits students by improving how teachers relate to and support their students, encouraging students to become more self-reflexive as well as enhancing the awareness and support that teachers have toward their students. Finley (2008) stated that arts-based methods allow the researcher to find meaning through imaginative and creative interpretation. In this study, the use of arts-based methods as forms of methodological inventiveness in self-reflexive educational research provided the connections between the self and others in varying times and spaces. The past and the present as well as the interrelationship between multiple voices were explored, and this concluded in building a better understanding of my teacher identity.

\section{References}

Barone, T., \& Eisner, E. W. (2011). Arts based research. Thousand Oaks, CA: SAGE.

Block, D. (2007). The rise of identity in SLA research, post Firth and Wagner (1997). Modern Language Journal, 91, 863-876.

Block, D. (2013). Issues in language and identity research in applied linguistics. Estudios de Lingüística Inglesa Aplicada (ELIA), 13, 11-46. http://dx.doi.org/10.12795/elia.2013.i13.01

Brandenburg, R. (2009). Assumption interrogation: An insight into a self-study researcher's pedagogical frame. In D. L. Tidwell, M. L. Heston, \& L. M. Fitzgerald (Eds.), Research methods for the self-study of practice (pp. 195-211). Dordrecht, NL: Springer.

Bullough, R. V. Jr., \& Pinnegar, S. (2001). Guidelines for quality in autobiographical forms of self-study research. Educational Researcher, 30(3), 13-21.

Costa, A. L., \& Kallik, B. (1993). Through the lens of a critical friend. Educational Leadership, 51(2), 49-51.

Feldman, A. (2003). Validity and quality in self-study. Educational Researcher, 32(3), 2628).

Finley, S. (2008). Arts-based research. In J. G. Knowles \& A. L. Cole (Eds.), Handbook of the arts in qualitative research (pp. 71-82). London, UK: SAGE. 
Hopper, T., \& Sanford, K. (2008). Using poetic representation to support the development of teachers' knowledge. Studying Teacher Education, 4(1), 29- 45.

doi:10.1080/17425960801976339

Igoa, C. (1995). The inner world of the immigrant child. New York, NY: St. Martin's Press.

Johri, A. (2011). Culture of a writing class: Exploring students' writing personas in a multicultural alternative high school (Unpublished doctoral dissertation). George Mason University. Fairfax, VA.

Kahlo, F. (1933). My dress hangs there. [Painting]. Retrieved from https://www.fridakahlo.org/my-dress-hangs-there.jsp

Klein, E. J., Riordan, M., Schwartz, A., \& Sotirhos, S. (2008). Dissertation support groups: Building a community of practice using Noddings' ethic of care. In A. P. Samaras, A. R. Freese, C. Kosnik, \& C. Beck (Eds.), Learning communities in practice (pp. 117132). Dordrecht, NL: Springer.

Kolodji, D. P. (2005). Knowing what counts: The cinquain. Retrieved from http://www.shadowpoetry.com/resources/wip/cinquain.html

Kubota, R. (2004). Critical multiculturalism and second language education. In B. Norton \& K. Toohey (Eds.), Critical pedagogies and language learning (pp. 30-52).

Cambridge, UK: Cambridge University Press. May, S. (2012). Language and minority rights: Ethnicity, nationalism and the politics of language. Harlow, UK: Longman.

McKinney, C., \& Norton, B. (2008). Identity in language and literacy education. In B. Spolsky \& F. Hult (Eds.), The handbook of educational linguistics (pp. 192-205). Malden, MA: Blackwell

Mitchell, C. (2005). In my own handwriting: Textual evidence and self-study. In Kosnik, C., Beck, C. Freese, A. F., \& Samaras, A. P. (Eds.), Making a difference in teacher education through self-study: Studies in personal, professional, and program renewal (pp. 117-130). Dordrecht, NL: Springer.

Morgan, B. (2004). Teacher identity as pedagogy: Towards a field-internal conceptualisation in bilingual and second language education. International Journal of Bilingual Education and Bilingualism, 7(2/3), 172-188. doi:10.1080/13670050408667807

Naicker, S. (2014). Digital memory box as a tool for reflexivity in researching leadership practice. Educational Research for Social Change (ERSC), 3(2), 51-65.No Child Left Behind Act of 2001, 20 U.S.C. $§ 6319$ (2011).

Norton, B. (2000). Identity and language learning: Gender, ethnicity and educational change. Harlow, UK: Pearson. 
Norton, B., \& Toohey, K. (2011). Identity, language learning, and social change. Language Teaching, 44(4), 412-446. doi:10.1017/S0261444811000309

Norton Peirce, B. (1995). Social identity, investment, and language learning. TESOL Quarterly, 29(1), 9-31.

Pavlenko, A. (2006). Bilingual selves. In A. Pavlenko (Ed.), Bilingual minds: Emotional experience, expression, and representation (pp. 1-33). Clevedon, UK: Multilingual Matters. Retrieved from http://www.anetapavlenko.com/pdf/Bilingual_Selves.pdf

Pavlenko, A. (2012). Affective processing in bilingual speakers: Disembodied cognition? International Journal of Psychology, 47(6), 405-428. doi:10.1080/00207594.2012.743665

Pinnegar, S., \& Hamilton, M. (2009). Self-study of practice as a genre of qualitative research: Theory, methodology, and practice. Dordrecht, NL: Springer.

Pithouse-Morgan, K., \& Samaras, A. P. (2020). Methodological inventiveness in writing about self-study research: "Inventiveness in service." In J. Kitchen, A. Berry, S. M. Bullock, A. R. Crowe, M. Taylor, H. Guðjónsdóttir, \& L. Thomas (Eds.), 2nd international handbook of self-study of teaching and teacher education practices (134). Dordrecht, NL. Springer.

Pithouse-Morgan, K., \& van Laren, L. (2012). Towards academic generativity: Working collaboratively with visual artefacts for self-study and social change. South African Journal of Education, 32(4), 416-427. doi:10.15700/saje.v32n4a662

Pithouse-Morgan, K., Mitchell, C., \& Moletsane, R. (Eds.). (2009). Making connections: Self-study \& social action. New York, NY: Peter Lang.Richardson, L. (2003). Writing: A method of inquiry. In N. K. Denzin \& Y. S. Lincoln (Eds.), Collecting and interpreting qualitative materials (2nd ed., pp. 499-541). Thousand Oaks, CA: SAGE.

Rong, X., \& Hilburn, J. (2017). Immigration and education in North Carolina: The challenges and responses in a new gateway state. Rotterdam, NL: Sense Publishers.

Saldaña, J. (2009). The coding manual for qualitative researchers. Thousand Oaks, CA: SAGE.

Samaras, A. P. (2010). Explorations in using arts-based self-study methods. International Journal of Qualitative Studies in Education, 23(6), 719-736.

Samaras, A. P. (2011). Self-study teacher research: Improving your practice through collaborative inquiry. Thousand Oaks, CA: SAGE. 
Samaras, A. P., Hicks, M. A., \& Berger, J. G. (2004). Self-study through personal history. In J. J. Loughran, M. L. Hamilton, V. K. LaBoskey, \& T. Russell (Eds.), International handbook of self-study of teaching and teacher education practices (Vol. 12, pp. 905942). Dordrecht, NL: Springer.

Samaras, A., \& Sell, C. (2013). Please write: Using critical friend letter writing in teacher research. Teacher Education Quarterly, 40(4), 93-109.

Savin-Baden, M., \& Wimpenny, K. (2014). A practical guide to arts-related research. Rotterdam, NL: Sense Publishers.

Wade, S. E., Fauske, J. R., \& Thompson, A. (2008). Prospective teachers' problem solving in online peer-led dialogues. American Educational Research Journal, 45(2), 298-442.

Wang, Q., Coemans, S., Siegesmund, R., \& Hannes, K. (2017). Arts-based methods in socially engaged research practice: A classification framework. Art/Research International: A Transdisciplinary Journal, 2(2), 5-39.

Weber, S. (2014). Arts-based self-study: Documenting the ripple effect. Perspectives in Education, 32(2), 8-20. 